\title{
Zinc Status in Beta-Thalassemia Major
}

\author{
Edited by: Ksenija Bogoeva-Kostovska \\ Citation: Hasan KH, Aswad HA, Sofijanova A. Zinc Statu \\ in Beta-Thalassemia Major. Open Access Maced J Me \\ Sci. 2021 Feb 19; 9(B):149-153. https://doi.org/10.3889/ \\ oamjms. 2021.5688 \\ Keywords: $\beta$-thalassemia major; serum zinc; serum
ferritin; children \\ *Correspondence: Aspazija Sofijanova, University \\ Children's Hospital, Ss Cyril and Methodius \\ University, Skopje, Republic of Macedonia. \\ E-mail: aspaziculi@yahoo.com \\ Received: 09-Jan-202 \\ Revised: 16-Jan-202 \\ Accepted: 09-Feb-2021
Copyright: $\odot 2021$ Khalaf Hussein Hasan, Hasan Abdulla \\ Aswad, Aspazija Sofijanova \\ Funding: This research did not receive any financial support \\ competing interests exist \\ competing interests exist \\ Open Access: This is an open-access article distributed \\ NonCommercial 4.0 International License (CC BY-NC 4.0)
}

Khalaf Hussein Hasan ${ }^{1}$, Hasan Abdulla Aswad ${ }^{2}$, Aspazija Sofijanova ${ }^{3 *}$

${ }^{1}$ Department of Pediatrics, College of Medicine, University of Duhok, Duhok, Iraq; ${ }^{2}$ Jin Oncology and hematology Center, Directorate of Health, Duhok, Iraq; ${ }^{3}$ University Children's Hospital, Ss Cyril and Methodius University, Skopje, Republic of Macedonia

\section{Abstract}

BACKGROUND: Zinc is one of the most important minerals incorporated in the enzymes of the human body. Zinc may be deficient in patients with the $\beta$-thalassemia major with possible adverse outcomes.

AIM: The purpose of this study was to assess the serum zinc status in $\beta$-thalassemia major patients in Duhok city.

PATIENTS, MATERIAL, AND METHODS: In this case-control study, 70 children with $\beta$-thalassemia major $(2-12$ years) of both genders were enrolled and were matched with 70 apparently healthy children for age and sex. A venous blood sample was obtained from each child for the measurement of serum zinc and serum ferritin levels at Jin Center in Duhok City between January 1 and June 30, 2017.

RESULTS: The mean serum zinc in the thalassemia patients $(74.79[ \pm 25.14] \mu \mathrm{g} / \mathrm{dl})$ was significantly lower compared to the control group $(93.61[ \pm 15.12] \mu \mathrm{g} / \mathrm{dl}),(\mathrm{p}=0.0001)$. The serum zinc was not significantly different in thalassemia patients in terms of age, disease onset, gender, height, weight, body mass index, amount of blood transfusion, and type of chelation. There was a statistically significant correlation between serum zinc levels with a serum ferritin leve of patients.

CONCLUSION: The study showed that thalassemia patients have significantly lower serum levels of zinc with no relation to medical factors.

\section{Introduction}

In humans, thalassemia is considered one of the most common hereditary blood disorders [1], [2]. About 150 million people carry the gene of thalassemia worldwide. The disease most commonly is seen in Africa, the Mediterranean region, and South-east Asia. The incidence may be as high as $10 \%$ in these regions [3]. Iran and Iraq are among the countries with the highest prevalence of major thalassemia [4], [5]. The clinical features of the disease may not be obvious until a complete conversion occurs from fetal to adult hemoglobin $(\mathrm{Hb})$. Typically, the switch is completed by the age of 6 months [3].

The most severe form of thalassemiais $\beta$-thalassemia major which requires frequent blood transfusions followed by giving iron-chelating agent (Desferroxamine) [6]. Thalassemia is a group of inherited blood-borne disorders due to abnormal $\mathrm{Hb}$ chain synthesis (either alpha or beta chain). The lack of beta-chain synthesis causes beta-thalassemia, which causes the body to form new abnormal red blood cells (RBCs), leading to anemia. The abnormal $\mathrm{Hb}$ chain syntheses need about 200-point mutations in that particular chain of $\mathrm{Hb}$. Beta-thalassemia major is a severe form of this blood disorder, where transfusion is the only hope for survival among patients, and a bone marrow transplant is a possible way to cure [3].
Zinc is an essential micronutrient for human health. It is vital for activating growth and physical and neurological development in infants, children, and adolescents. It is found in all parts of the body. It is a component in more than 300 enzymes and influences hormones. Zinc also accelerates cell division and enhances the immune system. It is vital in protecting the body from illnesses and fighting infections. It also participates in the metabolism of $\mathrm{CHO}$, lipids, and proteins, which, in turn, leads to good food utilization. Zinc also enhances Vitamin $D$ effects on bone metabolism [7].

Zinc deficiency observed in beta-thalassemia patients might have resulted in growth retardation through different mechanisms. Increased urinary zinc excretion has been described in thalassemia. Recent reports have suggested a link between increased urinary zinc excretion and renal tubular cell dysfunction in thalassemic patients [8]. There have been few studies of hyperzincuria in thalassemia major and its association with the iron chelator desferrioxamine, but, however, the results have been inconsistent [9].

Chronic blood transfusions in hemolytic disorders like $\beta$-thalassemia major may change the micronutrient status including zinc [10]. Zinc is a trace component, implicated in the synthesis of many other substances such as cholesterol, lipids and a lot of enzymes, immune, and antioxidant systems [11], [12]. Furthermore, it has an important role in protein synthesis, 
cell division, wound repairing, and improving visual acuity [8]. Zinc has the main role in the RBC life cycle and its lack leads to increased RBCs breakdown [12].

Zinc deficiency could be a possible cause of delayed maturity in beta-thalassemia major patients [13], [14]. There is an evident gap in zinc status in patients with a $\beta$-thalassemia major in this region. Therefore, this study aimed to measure the serum zinc levels $\beta$-thalassemia major compared to a healthy control group. In addition, the role of medical and general characteristics on serum zinc level in $\beta$-thalassemia major was examined in this age-sex match study.

\section{Patients and Methods}

A total of 70 children previously diagnosed with $\beta$-thalassemia major (2-12 years) of both genders were included in this age- and sex-matched casecontrol study. The cases were matched for age and sex with 70 apparently healthy controls. The serum zinc concentrations were compared between cases and controls. The patients were included from Jin center in Duhok city. The healthy children were selected from Heevi Pediatric Teaching Hospital with no history of chronic diseases. The Jin center provides care for thalassemia patients in Duhok Governorate, Iraqi Kurdistan. The data collection was done for a six month period between January 1 and June 30, 2017.

\section{Inclusion and exclusion criteria}

The patients who were diagnosed with $\beta$-thalassemia major up to 12 years old of both genders with no other medical chronic diseases met eligibility criteria for this study. The following children were excluded from the study; thalassemic children who were receiving multivitamins and $\mathrm{Zn}$ supplementation therapy, thalassemia children with any acute illness or any other chronic disease such as liver failure and heart failure.

\section{Data collection and measurement}

The following information was collected from the children and was recorded in a pre-designed questionnaire. The age, gender, onset age of disease (before one year and after one year), types of chelation (Desferrioxamine, Deferasirox (Exjade), Both Desferrioxamine and Deferasirox, ot none). Body mass index (BMI) was categorized as normal, underweight, overweight, or obese.

To measure serum zinc, $3 \mathrm{ml}$ venous blood was aspirated after cleaning the skin with a $70 \%$ alcohol swab. The blood was poured into a gel tube. Then, it was centrifuged at 4000 rotation per minute for 10 minutes. The serum was separated and collected in a plain tube labeled numerically for the measurement of serum Zn using atomic absorption spectrophotometer with a normal range of serum $\mathrm{Zn}$ is $70-115 \mu \mathrm{g} / \mathrm{dl}$, and serum ferritin with normal range (20-300 ng/dl in male and 14-150 ng/dl in females) [15]. The serum zinc levels were categorized as; normal serum zinc: $70-115 \mu \mathrm{g} / \mathrm{dl}$, high serum zinc: $>115 \mu \mathrm{g} / \mathrm{dl}$, mild Zn deficiency: 50-70 $\mu \mathrm{g} / \mathrm{dl}$, and severe $\mathrm{Zn}$ deficiency: $<50 \mu \mathrm{g} / \mathrm{dl}$ [15].

\section{Serum ferritin}

\section{Ethical considerations}

The study was approved by the Ethical Committee of the Directorate General of Health/Duhok, Jin Center, and Heevi Pediatric Teaching Hospital. Written consent was obtained from the children's' parents before the interviews were carried out.

The ethical approval of the protocol was obtained from the Council of the College of Medicine at the University of Duhok.

\section{Statistical analysis}

The homogeneity of children in terms of age and gender was examined in a Pearson Chi-squared test. The concentration of serum zinc was presented in mean (SD). The mean level of serum zinc between patients with $\beta$-thalassemia major and their controls was examined in an independent t-test. The significant level of difference was set at a $p<0.05$. The statistical analyses were performed by Statistical Package for the Social Sciences version 25 (IBM SPSS Statistics for Windows, Version 25.0. Armonk, NY: IBM Corp).

\section{Results}

Table 1 shows that the thalassemia patients and their control were comparable in gender $(p=0.864)$ and age distribution $(p=0.741)$

Table 1: Age and gender distribution

\begin{tabular}{lllllll}
\hline \multirow{2}{*}{ Age (years) } & \multicolumn{2}{l}{ Thalassemic patients } & & Controls & & p-value \\
\cline { 2 - 3 } & Male & Female & & Male & Female & \\
\hline 2-4 years & $9(12.8)$ & $10(14.2)$ & & $8(11.4)$ & $9(12.8)$ & 0.741 \\
5-9 years & $13(18.6)$ & $20(28.57)$ & & $13(18.6)$ & $20(28.57)$ & \\
10-12 years & $7(10)$ & $11(15.71)$ & & $9(12.8)$ & $11(15.71)$ & \\
Total & $29(41.42)$ & $41(58.58)$ & $30(42.85)$ & $40(57.15)$ & 0.864 \\
\hline
\end{tabular}

The mean serum Zn levels in thalassemic patients and controls

$\begin{array}{clcl}\text { The } & \text { serum zinc concentration in } \\ \beta \text {-thalassemic } & \text { patients was significantly lower }\end{array}$


(Mean: $74.79 \mu \mathrm{g} / \mathrm{dl}$ ) compared to healthy controls (Mean: $93.61 \mu \mathrm{g} / \mathrm{dl} ; \mathrm{p}=0.0001)$, Table 2.

Table 2: The mean serum $\mathrm{Zn}$ levels in thalassemic patients and controls

\begin{tabular}{llll}
\hline Study groups & Mean $(\mathrm{SD}) \mu \mathrm{g} / \mathrm{dl}$ & $\mathrm{t}$-test & $\mathrm{p}$-value \\
\hline Patients & $74.79(25.14)$ & -5.785 & 0.0001 \\
Controls & $93.61(15.12)$ & & \\
\hline An independent t-test was performed for statistical analysis. & &
\end{tabular}

The study showed that age of onset of disease, type of chelation, BMI, residence, and age have no association with serum zinc levels in $\beta$-thalassemic patients (Table 3 ).

Table 3: Association of patients' characteristics with serum zinc levels

\begin{tabular}{|c|c|c|c|c|c|}
\hline \multirow[t]{2}{*}{ Characteristics } & \multicolumn{5}{|c|}{ Zinc levels } \\
\hline & Normal & High & Mild & Severe & p-value \\
\hline \multicolumn{5}{|l|}{ Age of onset } & \multirow[t]{3}{*}{0.35} \\
\hline Below 1 year & 35 & 2 & 10 & 9 & \\
\hline Above 1 year & 7 & 1 & 3 & 3 & \\
\hline \multicolumn{5}{|l|}{ Type of chelation } & \multirow[t]{5}{*}{0.27} \\
\hline Desferrioxamine & 0 & 0 & 0 & 0 & \\
\hline Deferasirox (Exjade) & 36 & 3 & 12 & 10 & \\
\hline Both desferrioxamine and deferasirox & 4 & 0 & 1 & 0 & \\
\hline None & 2 & 0 & 0 & 2 & \\
\hline \multicolumn{5}{|l|}{ BMI } & \multirow[t]{5}{*}{0.08} \\
\hline Normal $\geq 18.5$ and $<25 \mathrm{~kg} / \mathrm{m}^{2}$ & 32 & 3 & 9 & 9 & \\
\hline Underweight $<18.5 \mathrm{~kg} / \mathrm{m}^{2}$ & 8 & 0 & 3 & 0 & \\
\hline Overweight $\geq 25$ and $<30 \mathrm{~kg} / \mathrm{m}^{2}$ & 2 & 0 & 1 & 1 & \\
\hline Obese $\geq 30 \mathrm{~kg} / \mathrm{m}^{2 * * *}$ & 0 & 0 & 0 & 2 & \\
\hline \multicolumn{6}{|l|}{ Residence } \\
\hline Urban & 26 & 3 & 8 & 5 & \multirow[t]{2}{*}{0.47} \\
\hline Rural & 16 & 0 & 5 & 7 & \\
\hline \multicolumn{6}{|l|}{ Age } \\
\hline $2-4$ years & 16 & 0 & 5 & 5 & \multirow[t]{3}{*}{0.96} \\
\hline $5-9$ years & 18 & 3 & 3 & 6 & \\
\hline $10-12$ years & 8 & 0 & 5 & 1 & \\
\hline \multicolumn{6}{|l|}{ Gender } \\
\hline Male & 19 & 3 & 3 & 4 & \multirow[t]{2}{*}{0.29} \\
\hline Female & 23 & 0 & 10 & 8 & \\
\hline
\end{tabular}

Severe Zn deficiency: $<50 \mu \mathrm{g} / \mathrm{dll}$. National Institutes of Health, 2000. BMl: Body mass index.

\section{The mean serum ferritin levels in thalassemic patients and controls}

The mean serum ferritin in thalassemic patients was significantly higher compared to its concentration in the controls (3217.57 vs. $46.37 \mathrm{ng} / \mathrm{dl} ; \mathrm{p}=0.001)$, Table 4.

Table 4: The mean serum ferritin levels in thalassemic patients and controls

\begin{tabular}{llll}
\hline Variable & Mean (SD) ng/dl & t-test & p-value \\
\hline Patients & $3217.57(2307.19)$ & 11.483 & 0.0001
\end{tabular}

Controls $\quad 46.37(28.48)$

An independent t-test was performed for statistical analysis. serum ferritin with normal range $(20-300 \mathrm{ng} / \mathrm{dl}$

in male and $14-150 \mathrm{ng} / \mathrm{dl}$ in females).

\section{Correlation Between Serum Zinc and Serum Ferritin of Both Case and Control Group}

There was a statistically significant correlation between serum zinc and serum ferritin of patients, while in controls, no significant correlation was noticed (Table 5).

Table 5: Correlation between serum zinc and serum ferritin of both case and control group

\begin{tabular}{llll}
\hline Details & Serum zinc mean (SD) $\mu \mathrm{g} / \mathrm{dl}$ & Serum ferritin mean $(\mathrm{SD}) \mathrm{ng} / \mathrm{dl}$ & $\mathrm{p}$-value \\
\hline Patients & $74.79( \pm 25.14)$ & $3217.57( \pm 2307.19)$ & 0.006 \\
Controls & $93.61( \pm 15.12)$ & $46.37( \pm 28.48)$ & 0.915 \\
\hline An independent t-test was performed for statistical analysis.
\end{tabular}

\section{Discussion}

In this study, mean serum Zn was below the normal range in patients in comparison with the mean serum $\mathrm{Zn}$ level of the controls in agreement with the literature [16]. Although zinc deficiency is common in beta-thalassemia major patients, it has no significant effect on physical growth and frequency of infections [17].

A study aimed to identify the zinc status and its effect on the growth and functions of young betathalassemia major patients. They included 40 patients with beta-thalassemia major and compared to ageand sex-matched 30 healthy control. They found that the serum zinc level in beta-thalassemia major patients was 44.7 (SD: $24.2 \mu \mathrm{g} / \mathrm{dl}$ ) compared to 63.3 (SD: $30.3 \mu \mathrm{g} / \mathrm{dl}$ ) in the controls. The mean serum zinc level was significantly lower in patients compared to the persons in the control group. In agreement with the findings of our study, they reported that age, gender, blood transfusion duration, and volume, mean pretransfusion $\mathrm{Hb}$ concentration, deferasirox dose, and serum ferritin level bear have not relation with serum zinc level in the patients group. Besides, serum zinc level was not found to associate with z-scores of stature, sitting, BMI, height index, and frequency of recent infections of patients [17].

Zinc deficiency in thalassemia major patients is determined by several factors, such as iron chelation therapy [18], ineffective erythropoiesis [19], increased hemolysis [19], and high prevalence of diabetes mellitus due to increased zinc losses [20].

Our study is consistent with the previous investigations [21], [22], [17]. In agreement with our study, several studies have shown that betathalassemia major patients have significantly lower serum zinc levels compared to healthy controls in the world [5], [14], [23].

Zinc deficiency in normal populations could be due to insufficientconsumption of food sources rich with zinc and frequent consumption of tea. Dietary habits, geographical factors, and ethnic background may affect the serum zinc status in these patients may be contributory (Theodoridis et al., 1998). Our patients were under deferasirox therapy as well, high prevalence of zinc deficiency could be explained by disturbances of zinc metabolism, renal dysfunction, and high urinary zinc excretion. Furthermore, poor dietary intake of micronutrients has been documented in children and adolescents with sickle cell diseases [24].

The prevalence of zinc deficiency is high in patients when comparing with normal healthy individuals; therefore, we can justify that the zinc deficiency in beta-thalassemia major patients could be further complicated by several factors. These factors are not specific to thalassemia disease. The variations in the geographical distribution of zinc content in the 
soil, insufficient consumption of zinc-rich food sources, malnutrition, and genetic differences.

No significant relationship was found between serum $\mathrm{Zn}$ and other variables, such as age, gender, age of disease onset, weight, height, BMI, amount of blood transfusion, and type of chelation. This finding is consistent with studies that were carried out in other countries [23], [25]. It is worth mentioning at this point that there were some limitations of this study, such as the small numbers of patients and control group and the unavailability of data concerning diet regimens.

A significant difference $(p=0.001)$ was observed between the mean serum ferritin levels in thalassemic patients in comparison with the controls. This finding is consistent with a study carried out in Los Angeles, the USA which revealed a significant increase in ferritin in the patient group [26]. Several studies have reported that zinc bears no relation to iron chelation therapy, serum ferritin level, and blood transformation [23], [27], [28], [29]. However, Galleno and Sulthan reported that zinc deficiency is related to iron chelation therapy [30], [31].

\section{Conclusion}

The study showed that thalassemia patients have significantly lower serum level of zinc with no relation to medical factors.

\section{References}

1. Weatherall DJ. Thalassaemia: The long road from bedside to genome. Nat Rev Genet. 2004;5(8):625-31. https://doi. org/10.1038/nrg1406 PMid: 15266345

2. Khan WA. Prevention is the only way to combat thalassemia. Daily Star. 2006;5(576):1-2.

3. Muncie HL, Campbell JS. Alpha and beta thalassemia. Am Fam Physician. 2009;80(4):339-44 PMid: 19678601

4. Merat A, Haghshenas M. The spectrum of beta - thalassemia mutations in Iran. Med J Islam Repub Iran. 2000;14(1):103-6.

5. Al-Samarrai AH, Adaay MH, Al-Tikriti KA, Al-Anzy MM. Evaluation of some essential element levels in thalassemia major patients in Mosul district, Iraq. Saudi Med J. 2008;29(1):94-7. PMid:18176681

6. Habibzadeh $F$, Yadollahie $M$, Merat A, Haghshenas $M$. Thalassemia in Iran; an overview. Arch Iran Med. 1998;1(1):27-33.

7. MacDonald RS. The role of zinc in growth and cell proliferation J Nutr. 2000;130(5):1500S-8.

PMid:10801966

8. Keikhaei B, Badavi M, Pedram M, Zandian K, Rahim F. Serum zinc level in thalassemia major. Pak J Med Sci. 2010;26(4):942-5.

9. Akar N, Tekin M, Uysal Z, Uzunali Ö. Effect of desferrioxamine on urinarycopperandzincexcretion in $\beta$-thalassemiamajorpatients. $J$ Trace Elem Exp Med. 2000;13(2):195-8. https://doi.org/10.1002/ (sici) 1520-670x(2000)13:2<195::aid-jtra2>3.0.co;2-9

10. Claster S, Wood JC, Noetzli L, Carson SM, Hofstra TC, Khanna R, et al. Nutritional deficiencies in iron overloaded patients with hemoglobinopathies. Am J Hematol. 2009;84(6):344-8. https:// doi.org/10.1002/ajh.21416

PMid:19415722

11. Prasad AS. Zinc in human health: Effect of zinc on immune cells. Mol Med. 2008;14(5-6):353-7. https://doi.org/10.2119/200800033.prasad

PMid:18385818

12. Tupe RS, Tupe SG, Tarwadi KV, Agte VV. Effect of different dietary zinc levels on hepatic antioxidant and micronutrients indices under oxidative stress conditions. Metabolism. 2010;59(11):1603-11. https://doi.org/10.1016/j. metabol.2010.02.020

PMid:20359724

13. Shamshirsaz AA, Bekheirnia MR, Kamgar M, Pourzahedgilani $N$ Bouzari N, Habibzadeh M, et al. Metabolic and endocrinologic complications in beta-thalassemia major: A multicenter study in Tehran. BMC Endocr Disord. 2003;3(1):4. https://doi. org/10.1186/1472-6823-3-4

PMid:12914670

14. Yazdideha M, Faranosh M. Evaluation of serum zinc in children affected with beta-thalassemic patients. Res Med. 2004;24(1):7-9.

15. Brown KH, Wuehler SE, Peerson JM. The importance of zinc in human nutrition and estimation of the global prevalence of zinc deficiency. Food Nutr Bull. 2001;22(2):113-25. https://doi. org/10.1177/156482650102200201

16. Nidumuru S, Boddula V, Vadakedath S, Kolanu BR, Kandi V. Evaluating the role of zinc in beta thalassemia major: A prospective case-control study from a tertiary care teaching hospital in India. Cureus. 2017;9(7):e1495. https://doi. org/10.7759/cureus.1495 PMid:28948115

17. Karunaratna AM, Ranasingha JG, Mudiyanse RM. Zinc status in beta thalassemia major patients. Biol Trace Elem Res. 2018;184(1):1-6. https://doi.org/10.1007/s12011-017-1158-0 PMid:28940159

18. Erdoğan E, Canatan D, Örmeci AR, Vural H, Aylak F. The effects of chelators on zinc levels in patients with thalassemia major. J Trace Elem Med Biol. 2013;27(2):109-11. https://doi. org/10.1016/j.jtemb.2012.10.002 PMid:23164519

19. Jansen J, Karges W, Rink L. Zinc and diabetes--clinical links and molecular mechanisms. J Nutr Biochem. 2009;20(6):399417. https://doi.org/10.1016/j.jnutbio.2009.01.009

20. Fung EB, Gildengorin G, Talwar S, Hagar L, Lal A. Zinc status affects glucose homeostasis and insulin secretion in patients with thalassemia. Nutrients. 2015;7(6):4296-307. https://doi. org/10.3390/nu7064296 PMid:26043030

21. Hettiarachchi M, Liyanage $C$, Wickremasinghe R, Hilmers DC Abrams SA. Prevalence and severity of micronutrient deficiency: A cross-sectional study among adolescents in Sri Lanka. Asia Pac J Clin Nutr. 2006;15(1):56. https://doi.org/10.1038/ sj.ejcn.1602791 PMid: 16500879

22. Marasinghe E, Chackrewarthy S, Abeysena C, Rajindrajith S. Micronutrient status and its relationship with nutritional status in preschool children in urban Sri Lanka. Asia Pac J Clin Nutr. 
2015;24(1):144-51.

PMid:25740753

23. Mahyar A, Ayazi P, Pahlevan AA, Mojabi H, Sehhat MR, Javadi A. Zinc and copper status in children with Betathalassemia major. Iran J Pediatr. 2010;20(3):297-302.

PMid:23056720

24. Kawchak DA, Schall JI, Zemel BS, Ohene-Frempong K, Stallings VA. Adequacy of dietary intake declines with age in children with sickle cell disease. J Am Diet Assoc. 2007;107(5):843-8. https://doi.org/10.1016/j.jada.2007.02.015 PMid:17467383

25. Mashhadi MA, Sepehri Z, Heidari Z, Shirzaee E, Kiani Z. The prevalence of zinc deficiency in patients with thalassemia in South East of iran, sistan and baluchistan province. Iran Red Crescent Med J. 2014;16(8):e6243. https://doi.org/10.5812/ ircmj.6243

PMid:25389495

26. Wood JC, Tyszka JM, Carson S, Nelson MD, Coates TD. Myocardial iron loading in transfusion-dependent thalassemia and sickle cell disease. Blood. 2004;103(5):1934-6. https://doi. org/10.1182/blood-2003-06-1919

PMid:14630822
27. Mehdizadeh M, Zamani G, Tabatabaee S. Zinc status in patients with major beta-thalassemia. Pediatr Hematol Oncol. 2008;25(1):49-54. https://doi.org/10.1080/08880010701773738 PMid: 18231954

28. El Missiry M, Hamed Hussein M, Khalid S, Yaqub N, Khan S, Itrat $F$, et al. Assessment of serum zinc levels of patients with thalassemia compared to their siblings. Anemia. 2014;2014:125452. https://doi.org/10.1155/2014/125452 PMid:25197566

29. Sherief LM, El-Salam A, Sanaa M, Kamal NM, Almalky MA, Azab SF, et al. Nutritional biomarkers in children and adolescents with beta-thalassemia-major: An Egyptian center experience. Biomed Res Int. 2014;2014:261761. https://doi. org/10.1155/2014/261761

PMid:24812610

30. Galanello R, Campus S. Deferiprone chelation therapy for thalassemia major. Acta Haematol. 2009;122(2-3):155-64. https://doi.org/10.1159/000243800

PMid:19907153

31. Sultan S, Irfan SM, Kakar J, Zeeshan R. Effect of iron chelator desferrioxamine on serum zinc levels in patients with beta thalassemia major. Malays J Pathol. 2015;37(1):35-8.

PMid:25890611 